\title{
Direct RAPD Evaluation of Bacteria without Conventional DNA Extraction
}

\author{
Welington Luiz Araújo ${ }^{1 *}$, Derlene Attili de Angellis ${ }^{1}$ and João Lúcio Azevedo ${ }^{1,2}$ \\ ${ }^{1}$ Laboratório de Genética de Microrganismos; Departamento de Genética; ESALQ/USP; wlaraujo@esalq.usp.br; \\ C. P. 83; 13400-970; Piracicaba - SP - Brazil. ${ }^{2}$ Núcleo Integrado de Biotecnologia; Universidade de Mogi das \\ Cruzes - São Paulo - Brazil
}

\begin{abstract}
The present work reports successful DNA amplification of Pantoea agglomerans and Bacillus pumilus through Random Amplified Polymorphic DNA (RAPD). For this, template DNA was obtained without conventional DNA extraction. The procedure was as follows: cultures grown for 20 hours in $5 \mathrm{~mL}$ LB medium were centrifuged and the resulting preparation was suspended in TE buffer. After boiling, the cell suspension was diluted and $2.0 \mu l$ were used in reactions of $15 \mu l$. The results showed no significant differences among the RAPD profile of the PCR reactions derived from the boiling and phenol extraction methods, suggesting the utilization of this method for genetic population analysis.
\end{abstract}

Key words: Bacteria, boiling method, DNA extraction, RAPD

\section{INTRODUCTION}

RAPD (Random Amplified Polymorphic DNA) technique is a powerful tool for genetic studies and has been simultaneously described by Williams et al. (1990) and Welsh and McClelland (1990). However, its use for genetic population analyses may be limited by the laborious procedures involved in the extraction of genomic DNA from large sets of samples. More simplified techniques were developed to overcome this problem, as those associating formamide to heating (Panaccio et al., 1993) or the use of specific buffers (Steiner et al., 1995; Hilton et al., 1997).

Recently, procedures such as boiling have been used to promote cell lysis and detect pathogens in plant tissues (Zhang and Goodwin, 1997; Sulzinski et al., 1997), or also to inactivate compounds such as proteinase $\mathrm{K}$, which may inhibit the Taq DNA polymerase (Goldenberger et al., 1995). However, these methods are still time consuming.

PCR reactions using DNA obtained by cell boiling is a routine in many laboratories worldwide, however, in RAPD analysis this strategy has not been used. Analyses reported by Stephan et al. (1994) mention a RAPD reaction with DNA of Bacillus licheniformis extracted by cell boiling, but little information concerning the efficiency and sensibility of this technique was given. Here we investigate these aspects through the density of cells in each reaction.

\section{MATERIALS AND METHODS}

\section{Bacterial isolates}

The endophytic bacteria Pantoea agglomerans (strain T045) and Bacillus pumilus (strain LD31)

\footnotetext{
* Author for correspondence
} 
originally isolated from citrus hybrid (Citrus paradisi Macf. X $C$. reticulata Blanco) and $C$. sinensis Osbeck, respectively (Araújo et al., 2001) were used in the present analysis.

\section{Determination of bacterial density}

Bacteria were grown in $5.0 \mathrm{~mL}$ of $\mathrm{LB}$ medium $(0.5 \%$ yeast extract, $1 \%$ tryptone, $1 \% \mathrm{NaCl})$ and appropriated dilutions were plated on LBA medium (LB plus 1.5\% agar) for determination of the number of colony forming units (CFU). Colony counts were made after 24 hours of incubation at $28^{\circ} \mathrm{C}$. At least four repetitions were performed.

\section{Preparation of DNA samples for RAPD}

Two methods of DNA extraction were used: phenol extraction method (PM) and boiling cells (BC). For the $\mathrm{BC}$ method, bacteria were grown for 20h, until log phase, and were centrifuged (4000 g; $2 \mathrm{~min}$ ), washed in $0.85 \% \mathrm{NaCl}$ solution and centrifuged again. The pellet was ressuspended in $1.0 \mathrm{~mL}$ of TE buffer (EDTA $1.0 \mathrm{mM}$; Tris- $\mathrm{HCl} 10$ $\mathrm{mM}, \mathrm{pH}=8.0$ ) and boiled for $15 \mathrm{~min}$. Serial dilutions with Tris- $\mathrm{HCl}(10 \mathrm{mM}, \mathrm{pH}=8.0)$ were made and $2.0 \mu \mathrm{L}$ of the appropriate dilutions used in RAPD reactions.

For PM, total DNA was extracted from bacterial cultures in LB broth. After $24 \mathrm{~h}, 50 \mathrm{~mL}$ of culture was removed and centrifuged at $3000 \mathrm{~g}$ for $5 \mathrm{~min}$, after which the cells were washed in $0.85 \% \mathrm{NaCl}$ solution, re-centrifuged and resuspended in $2 \mathrm{~mL}$ of TEN buffer (100 mM EDTA; $150 \mathrm{mM} \mathrm{NaCl}$; $100 \mathrm{mM}$ Tris- $\mathrm{HCl}, \mathrm{pH}=8.0$ ) containing $4 \mathrm{mg} \cdot \mathrm{mL}^{-1}$ lysozyme. The suspension was incubated at $37^{\circ} \mathrm{C}$ for $45 \mathrm{~min}$ and $0.5 \mathrm{~mL}$ of $8.5 \%$ SDS was added, followed by incubation at $75^{\circ} \mathrm{C}$ for $30 \mathrm{~min}$ before the addition of $1.5 \mathrm{~mL}$ of potassium acetate $(5 \mathrm{M}$, $\mathrm{pH}=5.2$ ) and incubation for $20 \mathrm{~min}$ at $4^{\circ} \mathrm{C}$. The DNA was extracted with phenol - chloroform isoamylalcohol, precipitated with isopropanol (Sambrook et al., 1989), washed with $70 \%$ ethanol, briefly dried and re-suspended in $200 \mu \mathrm{L}$ of TE buffer.

\section{RAPD analysis}

RAPD analysis was carried out in $15 \mu \mathrm{L}$ final volume, containing $2.5 \mathrm{ng}$ of DNA template or 2.0 $\mu 1$ of diluted boiled bacterial culture, $0.4 \mathrm{mM}$ primer, $200 \mu \mathrm{M}$ each of dCTP, dGTP, dATP and dTTP (Pharmacia), $5 \mathrm{mM} \mathrm{MgCl}_{2}$ and $1.5 \mathrm{U}$ of Taq DNA polymerase (Gibco - Life Technologies) in
$20 \mathrm{mM}$ Tris $-\mathrm{HCl}, \mathrm{pH}=8.4$ containing $50 \mathrm{mM} \mathrm{KCl}$. The thermal cycling profile was as follows: $4 \mathrm{~min}$ initial denaturation at $92^{\circ} \mathrm{C}, 40$ cycles of $1 \mathrm{~min}$ at $92^{\circ} \mathrm{C}, 2 \mathrm{~min}$ at $37^{\circ} \mathrm{C}, 3 \mathrm{~min}$ at $72^{\circ} \mathrm{C}$, followed by a final extension at $72^{\circ} \mathrm{C}$ for $3 \mathrm{~min}$. PCR products were analysed in $1.4 \%$ agarose gels stained with ethidium bromide. Negative controls contained water instead of DNA.

The primers used were OPE-14 (5'-TCG GGC TGA G-3'), OPE-19 (5'-ACG GCG TAT G-3'), OPE-20 (5'-AAC GGT GAC C-3'), OPX-09 (5'GGT CTG GTT G-3'), OPX-16 (5'-CTC TGT TCG G-3'), OPE-12 (5'-TTA TCG CCC C-3') and OPX-18 (5'-TGG CAA GGC A-3'), supplied by Operon Technologies (Alameda, CA, EUA).

\section{RESULTS AND DISCUSSION}

In the present analysis, RAPD patterns obtained from bacteria had no significant differences between BC and PM methods (Figs. 1 and 2). Besides, the RAPD observed fragments ranged from 0.4 to $2.1 \mathrm{~kb}$, suggesting that long DNA template was kept in the cell suspension, since degraded DNAs usually yielded low molecular weight PCR products (Steiner et al., 1995). These results showed that $\mathrm{BC}$ might be helpful in studies using a high number of samples, since it was less expensive than any other methodology currently used.

However, the reduction of bacterial cell number in reaction changed the amplification pattern, increasing the unspecific and no repeatable pattern (Figs 1 and 2). At low number of CFU in the RAPD reaction, a loss of reliable bands was observed, probably due to a minimal concentration of DNA template (Figs. 1 and 2). Similar results were previously observed (Welsh and McClelland, 1990).

The BC method was more sensitive for RAPD analysis of $P$. agglomerans, a Gram-negative bacterium, than in B. pumilus, a Gram-positive bacterium. Reproducible RAPD patterns were obtained with $10^{5}-10^{3}$ CFU of $P$. agglomerans cells. At the same cell concentration, the RAPD patterns of B. pumilus, a Gram-positive bacterium, were not reproduced. The difference in sensitivity observed could be explained by cell wall differences between these bacteria. 
A

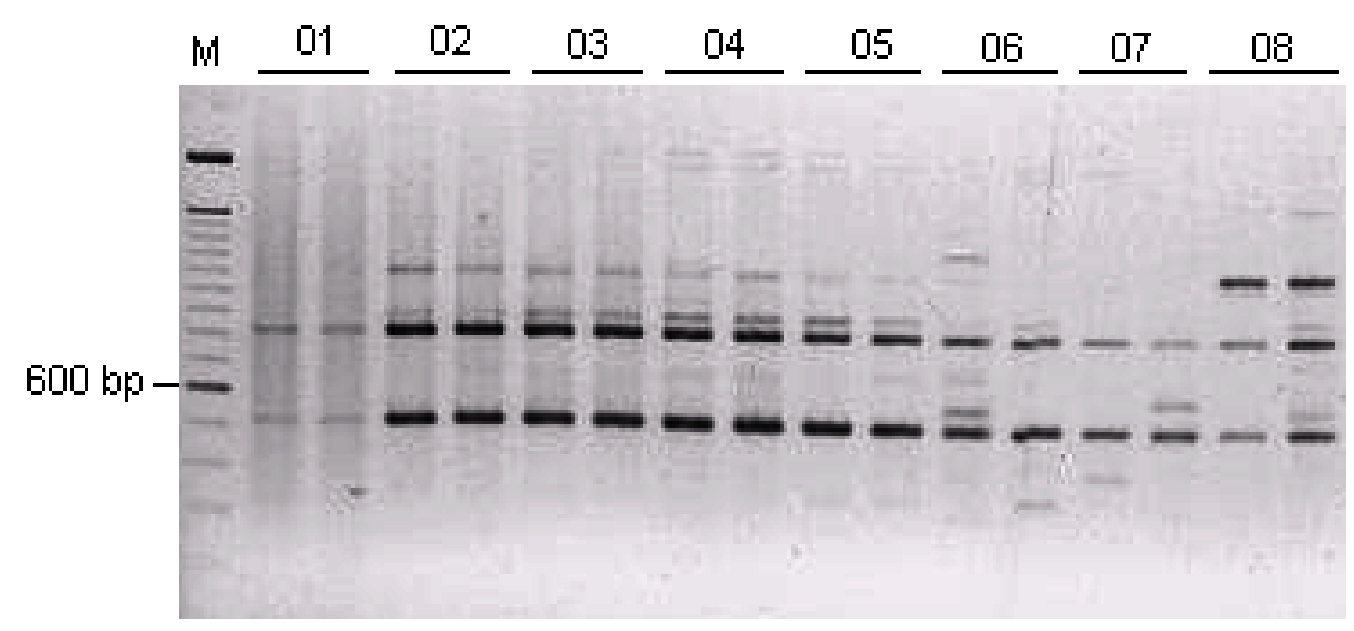

B

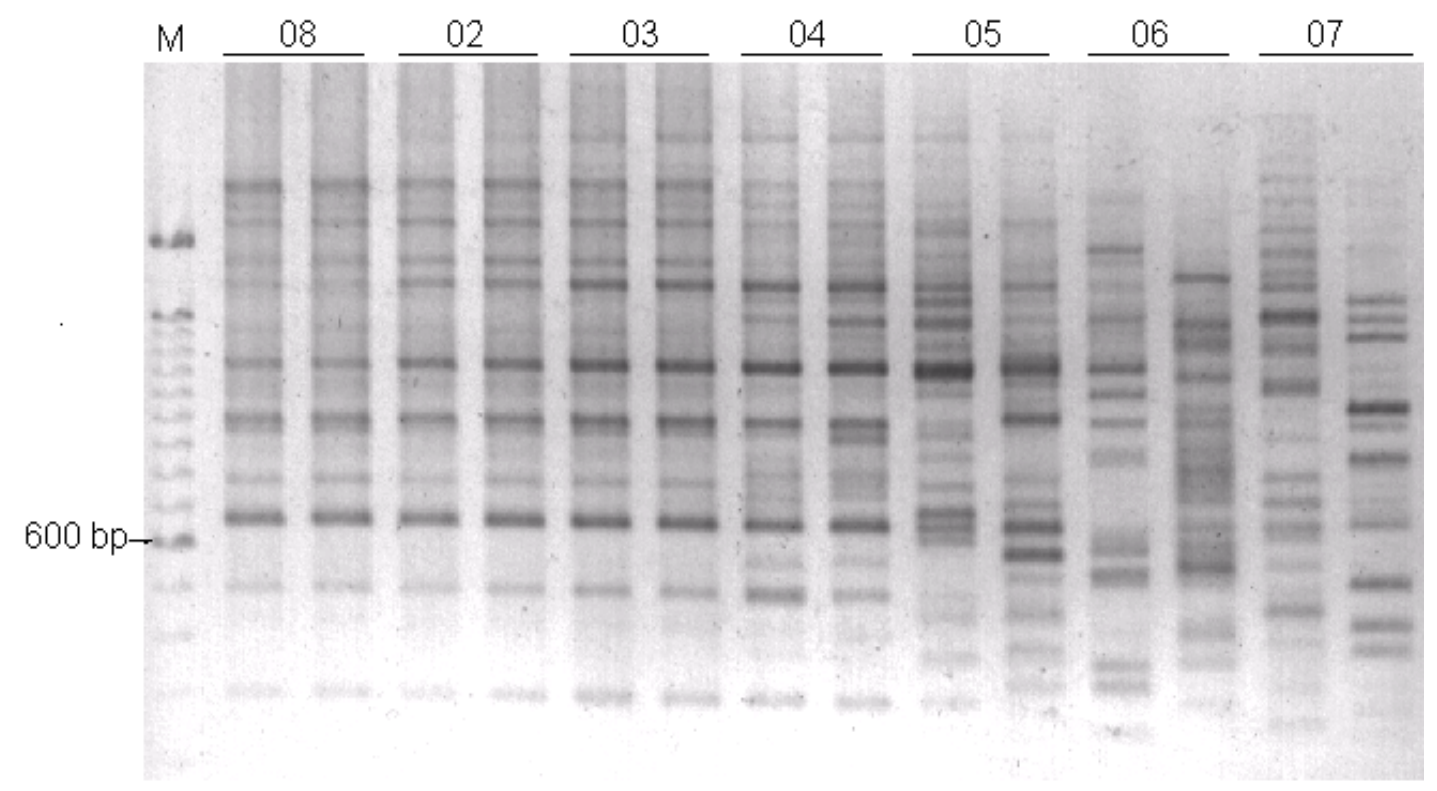

Figure 1 - Variation in P. agglomerans RAPD profile using primers (A) OPX-09 (B) OPE-19. Number of cells used per PCR mix: (1) $10^{6} \mathrm{CFU}$; (2) $10^{5} \mathrm{CFU}$; (3) $10^{4} \mathrm{CFU}$; (4) $10^{3}$ CFU; (5) $10^{2} \mathrm{CFU}$; (6) $10^{1} \mathrm{CFU}$; (7) $1 \mathrm{CFU}$; (8) DNA extracted by PM method; (M) 100 bp DNA ladder (Gibco - Life Technologies). 
A

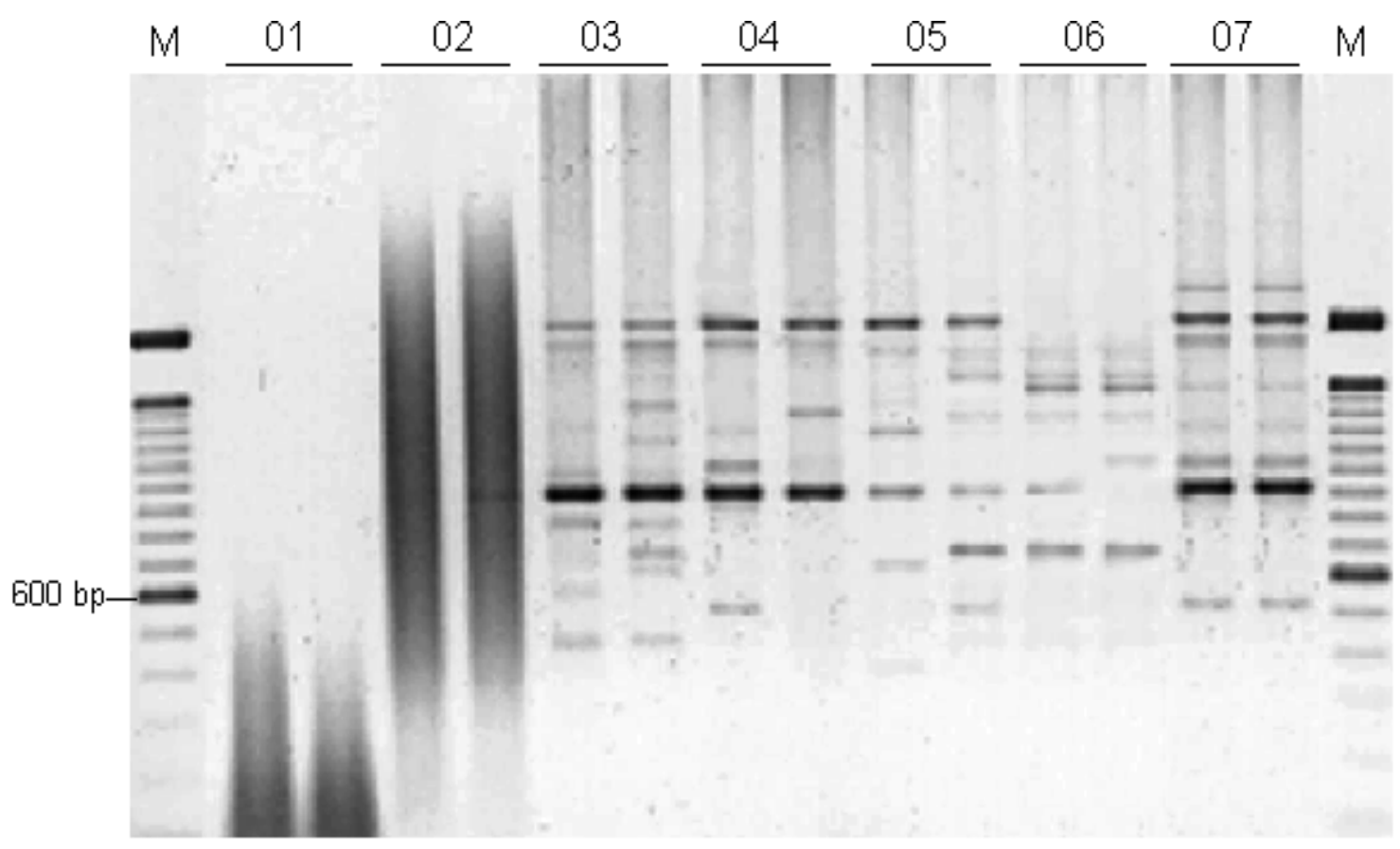

B

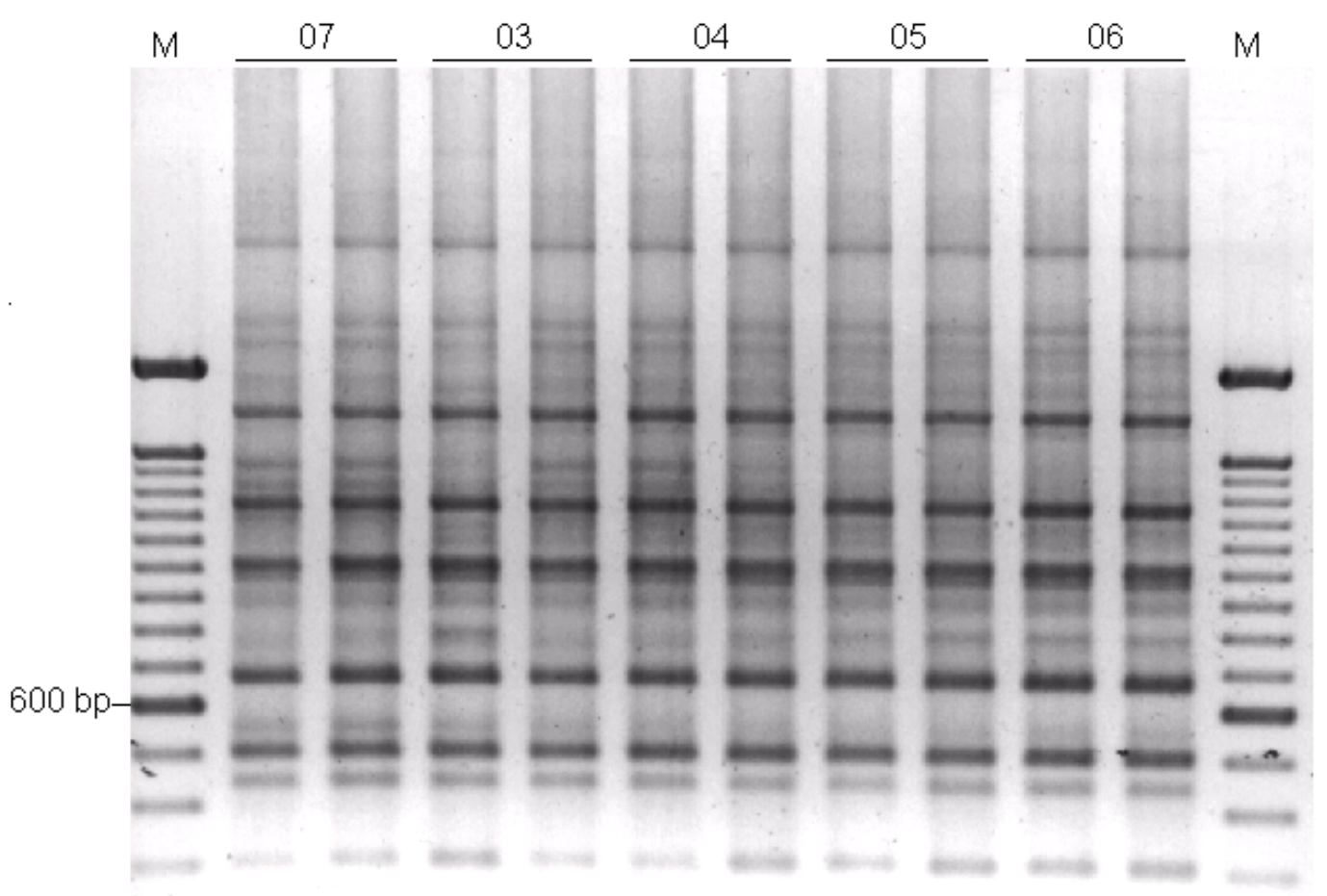

Figure 2 - Variation in B. pumilus RAPD profile using primers (A) OPX-09 and OPE-19. Number of cells used per PCR mix: (1) $10^{8} \mathrm{CFU}$; (2) $10^{7} \mathrm{CFU}$; (3) $10^{6} \mathrm{CFU}$; (4) $10^{5}$ CFU; (5) $10^{4} \mathrm{CFU}$; (6) $10^{3}$ CFU; (7) DNA extracted by PM method; (M) $100 \mathrm{bp}$ DNA ladder (Gibco - Life Technologies). 
Zhang and Goodwin (1997) reported that the PCR technique might detect $1.25 \times 10^{3}$ CFU.ml ${ }^{-1}$ of Xanthomonas fragariae suspension, using a method similar to the BC method plus an auxiliary buffer to break the cells. At high cell density, DNA amplification in the RAPD reaction was inhibited, but successive dilutions of boiled cells avoided this inhibition, suggesting that a high DNA concentration or inhibitory compounds could be responsible for this result. The most reliable cell concentration ranged from $10^{3}$ to $10^{5}$ and from $10^{5}$ to $10^{6} \mathrm{CFU}$ per PCR mix for P. agglomerans and $B$. pumilus, respectively (Figs 1 and 2). More studies should be performed for a better understanding of the details related to the RAPD technique. Here, we determined the number of cells needed for a reliable RAPD reaction. Other simplified methods to obtain DNA template for PCR have been described. However, the boiling method seems to be very efficient, simple and may be used in the RAPD technique. The low number of steps required in this procedure was one of the positive aspects, because a higher number of samples could be processed per day. Another advantage was that it was not necessary to change tubes during incubation. Besides, the $\mathrm{BC}$ method did not produce hazardous wastes (table 1), it was much less expensive and special drugs or equipments were not necessary. Therefore, this study suggest that the $\mathrm{BC}$ method was the most convenient method to obtain DNA for genetic population analyses through RAPD markers, which did not need purified DNA. Also, this method could be used with bacterial colonies grown on solid media after bacterial isolation (data not shown).

Table 1 - Comparison of DNA extraction methods for use with RAPD and PCR amplification.

\begin{tabular}{l|c|c|c|c}
\hline \multicolumn{1}{c|}{ Characteristics } & BC $^{\dagger}$ & Rose $^{\ddagger}$ & PM & Hilton \\
\hline Number of samples /day & $>3200$ & 1920 & 52 & 3000 \\
Number of steps* for extraction & 1 & 2 & 9 & 3 \\
Hazardous waste per day $(\mathrm{ml})^{£}$ & 0 & 0 & 300 & - \\
Number of reactions & $>5000$ & 13600 & 5000 & 5000 \\
\hline
\end{tabular}

*An extraction step is defined as any manipulation (e.g. different incubation), activity requiring the transfer of tube contents or the addition of reagents after the initial extraction solution is added to cells.

${ }^{\mathfrak{E}}$ Based on optimized number

${ }^{\dagger}$ This work

\$ Steiner et al. (1995)

" Hilton et al. (1997)

\section{CONCLUSIONS}

The $\mathrm{BC}$ could be a reliable method to obtain template DNA to use in RAPD analysis. It did not produce hazardous waste and was easier than others methods, which have currently been used in genetic population analysis. However, for routine application, it is recommended to use a range of tenfold dilution in duplicate, establishing the optimal cell number in PCR reaction. This optimisation adds robustness and reliability to the reactions, mainly in analysis of new species. This approach may greatly facilitate epidemiological, genetic and ecological studies of bacteria.

\section{ACKNOWLEDGEMENTS}

We thank Dr. Rosemeire Bueno for suggestions during this work. This work was supported by a grant from Foundation for Research Assistance, São Paulo State, Brazil (FAPESP) and by a grant by FUNDECITRUS (Fundo de Defesa da Citricultura, Araraquara, SP, Brazil). We thank FAPESP (Proc. $n^{\circ}$. 96/06686-4) for the Fellowship to W.L.A.

\section{RESUMO}

O presente trabalho mostra a amplificação de DNA das bactérias Pantoea agglomerans e Bacillus pumilus por meio da técnica de RAPD (Amplificação ao acaso de DNA polimórfico). Para esta análise, o DNA molde foi obtido sem a 
utilização de técnicas de extração convencional, ou seja, sem a purificação do DNA. Bactérias foram cultivadas por 20 horas em $5 \mathrm{~mL}$ de meio LB, centrifugado e ressuspendido em tampão TE. A suspensão resultante foi fervida por 5 min., diluída e $2,0 \mu \mathrm{L}$ foram usados em reações de $15 \mu \mathrm{L}$. Os resultados mostraram que os padrões observados com o DNA obtido pela fervura das células não apresentou diferenças significativas daquele obtido com DNA extraído e purificado com fenol, sugerindo a possibilidade da utilização deste método para o estudo da variabilidade genética de populações microbianas.

\section{REFERENCES}

Araújo, W. L.; Saridakis, H. O.; Barroso, P. A. V.; Aguilar-Vildoso, C. I.; Azevedo, J. L. (2001). Variability and interactions between endophytic bacteria and fungi isolated from leaf tissues of citrus rootstocks. Can. J. Microbiol., 47, 229-236.

Goldenberger, D.; Perschil, I.; Ritzler, M. and Atwegg, M. (1995), A simple "universal" DNA extraction procedure using SDS and proteinase $\mathrm{K}$ is compatible with direct PCR amplification. PCR Methods and Applications, 4, 368-370.

Hilton, A. C.; Banks, J. G. and Penn, C. W. (1997), Optimisation of RAPD for fingerprinting Salmonella. Lett. Appl. Microbiol., 24, 243-248.

Panaccio, M.; Georgesz, M.; Hollywell, C. and Lew, A. (1993), Direct PCR from solid tissues without DNA extraction. Nucleic Acids Res., 21, 4656.

Steiner, J. J.; Poklemba, C. J.; Fjellstrom, R. G. and Elliot, L. F. (1995), A rapid one-tube genomic DNA extraction process for PCR and RAPD analyses. Nucleic Acids Res., 23, 2569-2570.

Stephan, R.; Schraft, H. and Untermann, F. (1994), Characterization of Bacillus licheniformis with the RAPD technique (randomly amplified polymorphic DNA). Lett. Appl. Microbiol., 18, 260-263.
Sulzinski, M. A.; Moorman, G. W.; Schlagnhaufer, B. and Romaine, C. P. (1997), A simple DNA extraction method for PCR-based detection of Xanthomonas campestris pv. pelargonii in geraniums. J. Phytopathol., 145, 213-215.

Welsh, J. and Mcclelland, M. (1990), Fingerprinting genome using PCR with arbitrary primers. Nucleic Acids Res., 19, 303-306.

Williams, J. G. K.; Kubelik, A. R.; Livak, K. J.; Rafalski, J. A. and Tingey, S. V. (1990), DNA polymorphisms amplified by arbitrary primers are useful as genetic markers. Nucleic Acids Res., 18, 6531-6535.

Zhang, S. and Goodwin, P. H. (1997), Rapid and sensitive detection of Xanthomonas fragarie by simple alkaline DNA extraction and the Polymerase Chain Reaction. J. Phytopathol., 145, 267-270.

Received: March 20, 2002; Revised: December 27, 2002; Accepted: July 21, 2003. 